ISSN 1678-3921

Journal homepage: www.embrapa.br/pab

For manuscript submission and journal contents, access: www.scielo.br/pab
Paula Juliana Grotto Débia ${ }^{(1 凶)}(0$, Beatriz Cervejeira Bolanho(2) Heriksen Higashi Puerari(1) and Claudia Regina Dias-Arieira(1)

(1) Universidade Estadual de Maringá, Departamento de Ciência Agronômica, Estrada da Paca, s/no, São Cristóvão, CEP 87507-190 Umuarama, PR, Brazil. E-mail: paula.grotto@hotmail.com, heriksenhp@hotmail.com, crdiasarieira@hotmail.com

(2) Universidade Estadual de Maringá, Departamento de Tecnologia, Avenida Ângelo Moreira da Fonseca, № 1.800, CEP 87506-370 Umuarama, PR, Brazil. E-mail: beatrizbolanho@yahoo.com.br

${ }^{凶}$ Corresponding author

Received

April 4, 2018

Accepted

April 29, 2019

How to cite

DÉBIA, P.J.G.; BOLANHO, B.C.; PUERARI, H.H.; DIAS-ARIEIRA, C.R. Meloidogyne javanica parasitism and its impacts on the vegetative parameters, physicochemical composition, and antioxidant potential of beet. Pesquisa Agropecuária Brasileira, v.54, e00695, 2019. DOI: https://doi.org/10.1590/ S1678-3921.pab2019.v54.00695.

\section{Meloidogyne javanica parasitism and its impacts on the vegetative parameters, physicochemical composition, and antioxidant potential of beet}

\begin{abstract}
The objective of this work was to evaluate the effects of infestation by Meloidogyne javanica on the vegetative development, nutritional characteristics, and antioxidant potential of beet (Beta vulgaris). Inoculation in beet seedlings was performed with $0,1,000,2,500,5,000$, and 10,000 eggs and with possible second-stage juveniles (J2) of nematodes. Plants were collected 60 days after inoculation for the evaluation of the nematological and vegetative parameters, the physicochemical composition, and the content and activity of antioxidant compounds. The population levels of M. javanica reduced the mass and diameter of the tuber, comparing inoculum levels of 0 and 10,000 eggs $+\mathrm{J} 2$ of nematodes. There was a significant difference for the number of galls and nematodes per root system, with a proportional increase of population density according to the inoculation level. The reproduction factor in all infected treatments was above 1. Although the infection by $M$. javanica reduced the plant protein content, other compounds, such as betalains, sugars, and phenolics, were not affected. The inoculation by $M$. javanica negatively affects tuber development, but does not alter the antioxidant potential of beet.
\end{abstract}

Index terms: Beta vulgaris, betalains, gall nematodes, phenolic compounds, tuber.

\section{Parasitismo por Meloidogyne javanica e seus impactos sobre os parâmetros vegetativos, a composição físico-química e o potencial antioxidante da beterraba}

Resumo - O objetivo deste trabalho foi avaliar o efeito da infestação por Meloidogyne javanica sobre o desenvolvimento vegetativo, as características nutricionais e o potencial antioxidante da beterraba (Beta vulgaris). A inoculação foi feita em plântulas de beterraba com 0, 1.000, 2.500, 5.000 e 10.000 ovos e prováveis juvenis de nematoide em segundo estágio (J2). As plantas foram coletadas 60 dias após a inoculação, para a avaliação dos parâmetros nematológicos e vegetativos, da composição físico-química e do teor e da atividade dos compostos antioxidantes. Os níveis populacionais de $M$. javanica reduziram a massa e o diâmetro do tubérculo, comparando os níveis de inóculo 0 e 10.000 ovos $+\mathrm{J} 2$ de nematoide. Houve diferença significativa no número de galhas e nematoides por sistema radicular, com aumento proporcional da densidade populacional de acordo com o nível de inoculação. $\mathrm{O}$ fator de reprodução em todos os tratamentos com inoculação foi maior do que um. Embora a infecção por M. javanica tenha reduzido o teor de proteínas, outros compostos como betalaínas, açúcares e fenólicos não foram alterados. A infestação por $M$. javanica afeta negativamente o desenvolvimento do tubérculo, mas não altera o potencial antioxidante da beterraba.

Termos para indexação: Beta vulgaris, betalaínas, nematoides-das-galhas, compostos fenólicos, tubérculo. 


\section{Introduction}

Beet (Beta vulgaris L.) is commercially cultivated in Brazil due to its sensory characteristics and nutritional value (Stagnari et al., 2014; Carrillo et al., 2017). It contains approximately $1.9 \mathrm{~g}$ protein, $11.1 \mathrm{~g}$ carbohydrates, $3.4 \mathrm{~g}$ fiber, and $0.9 \mathrm{~g}$ ashes per $100 \mathrm{~g}$ of fresh weight (USDA, 2019). Its most abundant minerals are phosphorus $\left(867 \mathrm{mg} \mathrm{L}^{-1}\right)$, potassium $\left(2,825 \mathrm{mg} \mathrm{L}^{-1}\right)$, magnesium (259 $\left.\mathrm{mg} \mathrm{L}^{-1}\right)$, zinc $\left(1,132 \mu \mathrm{g} \mathrm{L}^{-1}\right)$, and iron $\left(2,206 \mu \mathrm{g} \mathrm{L}^{-1}\right)$ (Wruss et al., 2015). Besides, beet is a source of antioxidants such as phenolic compounds and betalains. Betalains are a class of pigments, formed by two structural groups, betacyanins and betaxanthins, which are responsible for the tuber's color; they can be used in the food industry as a source of natural color (Sawicki et al., 2016).

Beet production can be affected by a series of phytosanitary issues including nematodes belonging to the genera Heterodera and Meloidogyne (Held et al., 2000; Krall et al., 2000; Rosa et al., 2015). Meloidogyne incognita (Kofoid \& White) Chitwood and $M$. javanica (Treub) Chitwood frequently parasite horticultural plants, with gall formation in the tuberous root, resulting in yield and quality losses. Beet cultivar 'Oscarpoly', infected by M. javanica, showed a reduction of fresh root and shoot mass (Korayem, 2006). Hanse et al. (2011) and Melakeberhan et al. (2018) stated the importance of adequate nematode management to reduce losses in beet cultivation.

Nematode infestation can also affect the nutritional value of the products. Potatoes infected with $M$. arenaria showed reduced carbohydrates and sugars (Korayem et al., 2012). Besides, there is a research that points to an increase of the production of sugars and phenolic compounds in tomatoes infected by $M$. incognita (Atkinson et al., 2011), showing that plants respond differently to stress.

Despite the proven interaction between root-knot nematodes and beet, there are no known studies addressing its effects on the nutritional value of tubers, nor the antioxidant potential of beet. It is worth mentioning that tubers infected by nematodes are discarded due to changes in their physical characteristics, such as deformation and diameter reduction, and they do not meet the demands of in natura commercialization (Rosa et al., 2015). However, other alternatives can be proposed to minimize these losses, such as extraction of pigments, antioxidants, and other substances (Clifford et al., 2015). Thus, it is hypothesized that, although nematodes affect the production and commercial value of beets, the nutritional characteristics of the tubers may remain unchanged.

The objective of this work was to evaluate the effect of $M$. javanica parasitism on the vegetative development, nutritional quality, and antioxidant potential of beet.

\section{Materials and Methods}

The experiment was carried out between December 2014 and February 2015, in the greenhouse of the Nematology and Food Physicochemical Analysis Laboratory at Universidade Estadual de Maringá. Thirty-five plots were evaluated, each one composed of one plant, in a complete randomized design with four replicates, to analyze the vegetative and nematological parameters. Three replicates were conducted during the physicochemical composition and antioxidant analyses.

Beet 'Early Wonder Tall Top' (Top Seed) was sown in polystyrene trays containing vegetal substrat (Bioplant, Nova Ponte, MG, Brazil). After 20 days, seedlings were transplanted to pots (one seedling per pot) containing the following material: $2.8 \mathrm{~L}$ of sandy soil; Bioplant - composed of sphagnum peat, coconut fiber, rice husk, pine bark, vermiculite, and nutrients; and sand mixture (at 2:1:1). Prior to use, the mixture was autoclaved for 2 hours at $120^{\circ} \mathrm{C}$. Before planting, the soil was fertilized with granulated fertilizer containing $\mathrm{N}(40 \mathrm{~g}), \mathrm{P}_{2} \mathrm{O}_{5}(140 \mathrm{~g})$, and $\mathrm{K}_{2} \mathrm{O}(80 \mathrm{~g})$.

The seedlings were infected 7 days after transplantation at different $M$. javanica inoculum levels, consisting of $0,1,000,2,500,5,000$, and 10,000 eggs, and possible second-stage juveniles (J2) per plant. The inoculum was obtained from a pure population kept in okra plants, according to the methodology proposed by Hussey \& Barker (1973). The inoculum levels were evaluated by using Peters' slides under an optical microscope (BA210 Binocular, Motic, Hong Kong, China). Four (4) equidistant holes, approximately 3 $\mathrm{cm}$ deep, were opened in the soil around the plant for inoculation. The inoculum, held in $4 \mathrm{~mL}$ water, was deposited in the holes, which were subsequently closed. The plants were irrigated on a daily basis, depending on water requirements. Leaf fertilization was conducted every 15 days, using the leaf fertilizer Nutrijá at $380 \mathrm{~g}$ 
$\mathrm{N}, 380 \mathrm{~g} \mathrm{P}_{2} \mathrm{O}_{5}$, and $380 \mathrm{~g} \mathrm{~K}_{2} \mathrm{O}$ (Agrária, Jardinópolis, Brazil) diluted in water at a $5 \mathrm{~g} \mathrm{~L}^{-1}$.

After 60 days of inoculation, the plants were collected and carefully rinsed under running water to remove excess soil. Subsequently, shoots were separated from roots, and the following vegetative parameters were assessed: shoot fresh mass and height, secondary root and tuber mass, and tuber diameter. Shoot dry matter mass was also obtained after the samples were dried in a forced-air circulation oven for 3 days at $65^{\circ} \mathrm{C}$.

The number of galls per root system was first assessed to measure the nematological parameters through direct naked-eye counting. Subsequently, eggs were extracted from roots and tubers, according to the method proposed by Charchar et al. (2006). For this, beet tubers were peeled, and a thin peel slice of approximately $3 \mathrm{~mm}$ was removed from them. Peel slices and the secondary roots were cut in pieces ( 1 and $2 \mathrm{~cm}$ ) and ground in a blender (for $30 \mathrm{~s}$, at maximum speed), using hypochlorite solution at $0.5 \%$ to cover the plant material. The suspension was sieved through 60 and 500 mesh and washed in water; the content on the last sieve was collected in a beaker. Subsequently, eggs and J2 were counted on Peters' slide under an optical microscope. The total number of nematodes was divided by the root mass and expressed as nematodes per gram of root. The reproduction factor (RF) was also calculated based on the ratio between the final population (eggs $+\mathrm{J} 2)$ and the initial one (eggs $+\mathrm{J} 2)$ (Oostenbrink, 1966).

The treatments were analyzed to determine moisture, ash, and protein contents by the methods 925.09, 923.03, and 920.87, respectively, described by Horwitz \& Latimer (2005). The methodology proposed and adapted by Benkeblia \& Lopez (2015) was used for sugar extraction. Briefly, fresh beet samples $(5 \mathrm{~g})$ were homogenized in $50 \mathrm{~mL}$ ethanol at $80 \%$, and centrifuged at 1,650 $g$ (Metroterm, MTD III PLUS, Porto Alegre, RS, Brazil) for $10 \mathrm{~min}$. The supernatant was removed, and supernatant aliquots $(0.5 \mathrm{~mL})$ were placed in a forced-air circulation oven SL-102 (Solab, Piracicaba, SP, Brazil) at $50^{\circ} \mathrm{C}$, until complete ethanol evaporation. Subsequently, the samples were resuspended in $20 \mathrm{~mL}$ of Milli-Q water (Millipore, Burlington, MA, EUA); glucose, fructose, and sucrose were determined via high-efficiency ion exchange chromatography (Dionex ICS 5000, Thermo Fischer Scientific, Waltham, MA, USA). The samples were filtered through a PVDF hydrophilic membrane of
$0.22 \mu \mathrm{m}$ Millex-GV (Millipore, Burlington, MA, USA), and a total volume of $10 \mu \mathrm{L}$ was manually injected; separation was conducted in an analytical column CarboPac PA1 (Dionex Corporation, Sunnyvale, CA, USA). The run was performed at a solvent flow at 1.0 $\mathrm{mL} \mathrm{min}{ }^{-1}$ at $30^{\circ} \mathrm{C}$, using $\mathrm{NaOH}$ at $0.25 \mathrm{~mol} \mathrm{~L}^{-1}$ for 35 min. Chromatogram analysis was performed using the software package Chromeleon version 6.8 (Dionex Corporation, Sunnyvale, CA, USA). Calibration curves were generated using different glucose, fructose, and sucrose concentrations, obtained from Sigma-Aldrich (New Orleans, MO, USA) (Bolanho et al., 2015), and the results were expressed in $\mathrm{mg} \mathrm{g}^{-1}$ of sample on a wet basis.

Phenolic compounds and betalains were extracted according to Ravichandran et al. (2013), with modifications. Fresh samples $(1 \mathrm{~g})$ were dissolved in $20 \mathrm{~mL}$ ethanol at $50 \%$, stirred for 4 hours in an orbital stirrer MA-259 (Marconi, Piracicaba, SP, Brazil), and centrifuged in a MTD III plus(Metroterm, Porto Alegre, RS, Brazil) at 1,200 $\mathrm{g}$ for $10 \mathrm{~min}$. The supernatant was removed, and the extraction was repeated twice by using $5 \mathrm{~mL}$ ethanol at $50 \%$. Betalain content was determined in a spectrophotometer 700Plus (Femto, São Paulo, SP, Brazil), and the readings were conducted for betacyanins at $538 \mathrm{~nm}$, and for betaxanthins at 480 nm (Ravichandran et al., 2013). The concentrations were calculated using the following formula: betalain content $\left(\mathrm{mg} \mathrm{L}^{-1}\right)=[(\mathrm{A} \times \mathrm{DF} \times \mathrm{MM} \times 1000) /(\mathrm{e} \times 1)]$, in which: A is absorbance; DF is the dilution factor; and 1 is the bucket length. Molecular mass (MM) and the molar extinction coefficients (e) were used for betacyanin and betaxanthin quantification, respectively, as follows: $\mathrm{MM}=550 \mathrm{~g} \mathrm{~mol}^{-1} ; \mathrm{e}=60,000$ $\mathrm{L} \mathrm{mol}^{-1} \mathrm{~cm}^{-1}$ of $\mathrm{H}_{2} \mathrm{O} ; \mathrm{MM}=308 \mathrm{~g} \mathrm{~mol}^{-1} ; \mathrm{e}=48,000$ $\mathrm{L} \mathrm{mol}^{-1} \mathrm{~cm}^{-1}$ of $\mathrm{H}_{2} \mathrm{O}$.

The same extract was used to determine the contents of total phenolic compounds through the method of Folin-Ciocalteu, according to the protocol described by Chen et al. (2015), with modifications. Ethanolic beet extract $(0.5 \mathrm{~mL}), 10 \%$ Folin-Ciocalteu $(2 \mathrm{~mL})$, and $7.5 \%$ sodium carbonate $(2.5 \mathrm{~mL})$ were stirred and heated in a water bath at $50^{\circ} \mathrm{C}$ for $5 \mathrm{~min}$; absorbance was read at $760 \mathrm{~nm}$ in a spectrophotometer 700Plus (Femto, São Paulo, SP, Brazil). The calibration curve was prepared using gallic acid, and the results were expressed as gallic acid equivalent (GAE) in $\mathrm{mg} 100 \mathrm{~g}^{-1}$ of sample. 
Antioxidant activity, based on the 2,2-diphenyl-1picrylhydrazyl (DPPH) free-radical scavenge method, was determined according to Ravichandran et al. (2012), with some modifications. To prepare the solution, $0.011 \mathrm{~g}$ of DPPH (Sigma-Aldrich, New Orleans, MO, USA) was weighed and dissolved in $25 \mathrm{~mL}$ ethanol. Subsequently, $6 \mathrm{~mL}$ of this solution were dissolved in $100 \mathrm{~mL}$ of absolute ethanol. The reaction was carried out by using $3.80 \mathrm{~mL}$ of this DPPH solution, and 0.20 $\mathrm{mL}$ of ethanolic beet extract. Absorbance was read in a spectrophotometer 700Plus (Femto, São Paulo, SP, Brazil) at $515 \mathrm{~nm}$, after $30 \mathrm{~min}$ of incubation at room temperature. The antioxidant activity, based on the ferric- reducing/antioxidant power (FRAP) method, was determined by using a mixture containing 25

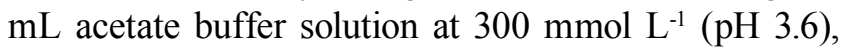
$2.5 \mathrm{~mL}$ of ferric chloride solution at $20 \mathrm{mmol} \mathrm{L}^{-1}$, and $2.5 \mathrm{~mL}$ of $10 \mathrm{mmol} \mathrm{L}^{-1} \mathrm{TPTZ}$ (2,4,6-Tris(2-pyridyl)s-triazine) dissolved in $40 \mathrm{mmol} \mathrm{L}^{-1} \mathrm{HCl}$ (WoottonBeard et al., 2011). A test tube containing $0.27 \mathrm{~mL}$ water and $90 \mu \mathrm{L}$ ethanolic extract was spiked with 2.7 $\mathrm{mL}$ of this mixture (FRAP reagent) for antioxidant capacity analysis. The tube was stirred and heated in a water bath at $37^{\circ} \mathrm{C}$ for $30 \mathrm{~min}$; absorption was read in a spectrophotometer 700Plus (Femto, São Paulo, SP, Brazil) at $593 \mathrm{~nm}$. Different Trolox (6-hydroxy-2,5,7,8tetramethylchroman-2-carboxylic acid) concentrations were used to generate the calibration curve through both antioxidant activity determination methodologies, and the results were expressed in $\mu \mathrm{mol}$ trolox $\mathrm{g}^{-1}$ of sample.

Data were subjected to the variance analysis through regression, to assess the parameters presenting significant differences, at $5 \%$ probability. To meet the assumptions of normality, vegetative parameters and nematological data were transformed to $(x+1)^{0.5}$. The analyses were performed using the statistical program Sisvar (Ferreira, 2011).

\section{Results and Discussion}

The beet cultivar used in the present work was susceptible to $M$. javanica; the reproduction factors at all treatments with inoculation were higher than 1 (Table 1). The number of galls found in roots of beet increased linearly with increasing inoculum application levels. However, nematodes per root system and per gram of roots, as well as the reproduction factor, increased up to 2,500 eggs $+\mathrm{J} 2$, and decreased in treatments with 5,000 and 10,000 eggs $+\mathrm{J} 2$. Based on previous studies, at higher inoculum levels, nematodes compete with each other for food and space, leading to a reduction of the population density. However, galls are formed early in the infestation, and therefore, gall number was not reduced (Asmus \& Ferraz, 2002; Di Vito et al., 2004; Vovlas et al., 2005).

The increased nematode population did not change the fresh shoot mass and the height of beet plants (Table 2). However, the increases of the dry shoot mass and the fresh root mass were directly proportional to the inoculum level used in the experiment. Most likely, this is because nematodes cause several physiological disturbances in the plants, mainly in the roots, leading

Table 1. Nematological parameters of Meloidogyne javanica 60 days after the inoculation of beet (Beta vulgaris) with different nematode population levels.

\begin{tabular}{lcccc}
\hline Initial population & NG & NRS & NRG & RF \\
\hline 0 & - & - & - & - \\
1,000 & $89^{*}$ & $3,732^{*}$ & $595^{*}$ & $3.73^{\text {ns }}$ \\
2,500 & 195 & 13,460 & 1,794 & 5.38 \\
5,000 & 226 & 10,180 & 1,720 & 2.03 \\
10,000 & 477 & 9,980 & 978 & 1.00 \\
\hline $\mathrm{R}^{2}$ & $91.19^{(1)}$ & $74.50^{(2)}$ & $89.50^{(3)}$ & - \\
$\mathrm{CV}(\%)$ & 30.00 & 41.20 & 32.24 & - \\
\hline
\end{tabular}

NG, number of galls; NRS, nematodes in the root system; NRG, nematodes per gram of root; $\mathrm{RF}$, reproduction factor. ${ }^{\text {ns Nonsignificant and }}$ *Significant at $5 \%$ probability; CV, coefficient of variation. ${ }^{(1)} \mathrm{y}=0.0431 \mathrm{x}$ $+38.085 .{ }^{(2)} \mathrm{y}=-0.0003 \mathrm{x}^{2}+4.018 \mathrm{x}+975.88 .{ }^{(3)} \mathrm{y}=-0.00006 \mathrm{x}^{2}+0.6758 \mathrm{x}$ +76.831 .

Table 2. Effect of Meloidogyne javanica on the vegetative parameters of beet (Beta vulgaris), 60 days after inoculation at different nematode population level.

\begin{tabular}{lcccccc}
\hline $\begin{array}{l}\text { Initial } \\
\text { population }\end{array}$ & $\begin{array}{c}\text { FSM } \\
(\mathrm{g})\end{array}$ & $\begin{array}{c}\text { DSM } \\
(\mathrm{g})\end{array}$ & $\begin{array}{c}\text { FRM } \\
(\mathrm{g})\end{array}$ & $\begin{array}{c}\text { SH } \\
(\mathrm{cm})\end{array}$ & $\begin{array}{c}\text { TM } \\
(\mathrm{g})\end{array}$ & $\begin{array}{c}\text { TD } \\
(\mathrm{mm})\end{array}$ \\
\hline 0 & $7.48^{\text {ns }}$ & $0.55^{*}$ & $1.82^{*}$ & $17.77^{\text {ns }}$ & $25.06^{*}$ & $34.31^{*}$ \\
1,000 & 6.51 & 0.90 & 9.16 & 18.37 & 18.15 & 32.38 \\
2,500 & 7.01 & 0.83 & 9.18 & 16.47 & 12.91 & 23.95 \\
5,000 & 9.45 & 1.09 & 6.83 & 18.42 & 11.93 & 23.44 \\
10,000 & 9.41 & 1.32 & 15.12 & 17.35 & 13.38 & 20.96 \\
\hline $\mathrm{R}^{2}$ & - & $87.15^{(1)}$ & $96.10^{(2)}$ & - & $99.98^{(3)}$ & $94.12^{(4)}$ \\
$\mathrm{CV}(\%)$ & 21.28 & 28.65 & 32.35 & 11.38 & 20.14 & 10.95 \\
\hline
\end{tabular}

FSM, fresh shoot mass; DSM, dry shoot mass; FRM, fresh root mass; $\mathrm{SH}$, shoot height; TM, tuber mass; TD, tuber diameter. ${ }^{\mathrm{n}}$ Nonsignificant and $*$ Significant at $5 \%$ probability. $\mathrm{CV}$, coefficient of variation. Original data transformed by $(\mathrm{x}+1)^{0.5}$ for statistical analysis. ${ }^{(1)} \mathrm{y}=-0.00000002 \mathrm{x}^{2}$ $+0.000242 \mathrm{x}+0.5596 .^{(2)} \mathrm{y}=0.00000001 \mathrm{x}^{2}+0.000862 \mathrm{x}+4.9662$. ${ }^{(3)} \mathrm{y}=0.0000003 \mathrm{x}^{2}-0.004356 \mathrm{x}+23.4654 .{ }^{(4)} \mathrm{y}=0.0000002 \mathrm{x}^{2}-0.003650 \mathrm{x}$ +34.3398 . 
to the formation of new secondary roots (Carneiro et al., 2002). In addition, the growth of the aerial part tends to be proportional to the growth of the root system (Leskovar, 1998).

Tubers were negatively affected by nematode infestation, with mass and diameter reductions (Table 2), which can be attributed to the fact that nematodes act as a photoassimilate drain in the plant (Premachandra \& Gowen, 2015), and may reduce the contents of important nutrients such as nitrogen, phosphorus, and potassium in beet cultivars (ElSherif et al., 2013). These results lead us to infer that photoassimilates are used in the formation of tubers for root and shoot maintenance. This hypothesis is supported by the fact that ash contents were reduced at a population level of 2,500 eggs $+\mathrm{J} 2$ of $M$. javanica (Table 3), as ashes represent mineral content present in the sample (Tivelli et al., 2011).

The different inoculum levels did not affect beet moisture (Table 3), which ranged from 814.5 to 855.4 $\mathrm{g} \mathrm{kg}^{-1}$ in the control and in the treatment with 10,000 eggs + J2. This result was similar to that reported by the United States Department of Agriculture in studies using fresh beet $\left(860 \mathrm{~g} \mathrm{~kg}^{-1}\right)$ (USDA, 2019). The control treatment showed the highest-protein content, $12.6 \mathrm{~g} \mathrm{~kg}^{-1}$ (Table 3); this value is similar to that detected in the beet 'Bikor' (13 to $14 \mathrm{~g} \mathrm{~kg}^{-1}$ ) (Petek et al., 2012). However, protein levels decreased linearly with increasing nematode populations, which may be related to the increase of the gall number - that was directly proportional to the inoculum levels; such gall are the same ones formed as a response to feeding of the nematodes (Hoth et al., 2005), and for which the nutrients, including proteins, are drained and directed to feed these pathogens.
No significant differences in the sugar contents were recorded among the treatments; sucrose was the most abundant sugar found in the tubers (Table 3). Beet is rich in sugars, with sucrose contents ranging from 28.4 to $29.3 \mathrm{~g} \mathrm{~kg}^{-1}$, depending on the cultivar and on the cultivation system (Bavec et al., 2010). Similarly, Atkinson et al. (2011) have reported that the sugar levels were maintained, when tomato plants were subjected to nematode stress. This fact can be associated to the high-metabolic activity in sick tissues, leading to a sugar-production compensation mechanism that can maintain sugar levels in plants infected by sedentary endoparasite nematodes (Nayak \& Mohanty, 2010).

There was no significant difference in the production of betalains and phenolic compounds as a result of the application levels of nematode inoculum (Table 4). Betacyanin and betaxanthin contents ranged from 5.22 to $10.26 \mathrm{mg} \mathrm{L}^{-1}$ and from 4.55 to $10.01 \mathrm{mg} \mathrm{L}^{-1}$, respectively; these values are within the range reported in the literature, namely of 7.00 to $8.50 \mathrm{mg} \mathrm{L}^{-1}$ for betacyanins, and 5.20 to $5.80 \mathrm{mg} \mathrm{L}^{-1}$ for betaxanthins

Table 3. Moisture, ash, protein, glucose, fructose, and sucrose contents, on a wet basis, of beet (Beta vulgaris) subjected to different Meloidogyne javanica population levels.

\begin{tabular}{lcccccc}
\hline $\begin{array}{l}\text { Initial } \\
\text { population }\end{array}$ & $\begin{array}{c}\text { Moisture } \\
\left(\mathrm{g} \mathrm{kg}^{-1}\right)\end{array}$ & $\begin{array}{c}\text { Ash } \\
\left(\mathrm{g} \mathrm{kg}^{-1}\right)\end{array}$ & $\begin{array}{c}\text { Proteins } \\
\left(\mathrm{g} \mathrm{kg}^{-1}\right)\end{array}$ & $\begin{array}{c}\text { Glucose } \\
\left(\mathrm{g} \mathrm{kg}^{-1}\right)\end{array}$ & $\begin{array}{c}\text { Fructose } \\
\left(\mathrm{g} \mathrm{kg}^{-1}\right)\end{array}$ & $\begin{array}{c}\text { Sucrose } \\
\left(\mathrm{g} \mathrm{kg}^{-1}\right)\end{array}$ \\
\hline 0 & $814.5^{\mathrm{ns}}$ & $12.1^{*}$ & $12.6^{*}$ & $2.80^{\text {ns }}$ & $1.70^{\text {ns }}$ & $17.1^{\mathrm{ns}}$ \\
1,000 & 823.5 & 12.6 & 11.9 & 2.90 & 1.80 & 16.5 \\
2,500 & 841.4 & 15.5 & 11.3 & 2.70 & 1.70 & 16.4 \\
5,000 & 814.5 & 11.9 & 10.0 & 2.60 & 1.70 & 16.8 \\
10,000 & 855.4 & 11.9 & 7.80 & 2.50 & 1.70 & 16.4 \\
\hline $\mathrm{R}^{2}$ & - & $77.55^{(1)}$ & $99.70^{(2)}$ & - & - & - \\
$\mathrm{CV}(\%)$ & 2.90 & 8.97 & 13.34 & 5.99 & 3.90 & 3.76 \\
\hline
\end{tabular}

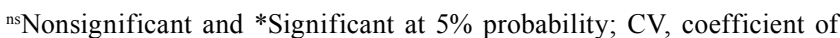
variation. ${ }^{(1)} \mathrm{y}=0.00000005+0.0004+12.63 .{ }^{(2)} \mathrm{y}=-0.00047 \mathrm{x}+1.25$.

Table 4. Contents of betacyanins, betaxanthins, phenolic compounds, and antioxidant activity via DPPH and FRAP methods, in beet (Beta vulgaris) subjected to inoculation at different Meloidogyne javanica levels.

\begin{tabular}{lccccc}
\hline $\begin{array}{l}\text { Initial } \\
\text { population }\end{array}$ & $\begin{array}{c}\text { Betacyanins } \\
\left(\mathrm{mg} \mathrm{L}^{-1}\right)\end{array}$ & $\begin{array}{c}\text { Betaxanthins } \\
\left(\mathrm{mg} \mathrm{L}^{-1}\right)\end{array}$ & $\begin{array}{c}\text { Phenolic compounds } \\
\left(\mathrm{mg} \mathrm{GAE} \mathrm{100} \mathrm{g}^{-1}\right)\end{array}$ & $\begin{array}{c}\text { DPPH } \\
\left(\mu \mathrm{mol} \mathrm{trolox} \mathrm{g}^{-1}\right)\end{array}$ & $\begin{array}{c}\text { FRAP } \\
\left(\mu \mathrm{mol} \mathrm{trolox} \mathrm{g}^{-1}\right)\end{array}$ \\
\hline 0 & $6.17^{\mathrm{ns}}$ & $7.23^{\mathrm{ns}}$ & $62.03^{\mathrm{ns}}$ & $42.86^{\mathrm{ns}}$ & $312.51^{\mathrm{ns}}$ \\
1,000 & 5.22 & 4.55 & 73.81 & 52.19 & 350.65 \\
2,500 & 10.26 & 10.01 & 80.88 & 66.35 & 413.19 \\
5,000 & 8.43 & 6.24 & 68.72 & 39.60 & 284.93 \\
10,000 & 7.04 & 7.97 & 64.26 & 43.78 & - \\
\hline $\mathrm{R}^{2}$ & - & - & - & 35.61 & 21.38 \\
$\mathrm{CV}(\%)$ & 26.72 & 39.56 & 23.80 & 35 & \\
\hline
\end{tabular}

${ }^{n s}$ Nonsignificant and *Significant at $5 \%$ probability. CV, coefficient of variation. 
(Ravichandran et al., 2013). The contents of phenolic compounds (62.03 to $80.88 \mathrm{mg}$ of GAE $100 \mathrm{~g} \mathrm{~g}^{-1}$ ) were also within the range reported in previous studies (50 to $100 \mathrm{mg}$ of GAE $100 \mathrm{~g} \mathrm{~g}^{-1}$ ) (Stagnari et al., 2014). These compounds are secondary metabolism products and related to defense mechanisms against pathogens, injuries, or other stress types (Naczk \& Shahidi, 2004). Against this background, the contents of these substances are expected to be relatively high in infected plants. However, it can be inferred that these compounds were used to maintain the development of the plants through the translocation of phytochemicals to other organs, such as leaves and stems, where the demand for antioxidants should be greater to maximize plant suitability in the environment (Taiz et al., 2017).

There were no significant differences for the antioxidant activity in the treatments evaluated, and values ranged from 39.60 to $66.35 \mu \mathrm{mol}$ trolox $\mathrm{g}^{-1}$ via the DPPH method, and from 284.93 to $413.19 \mu \mathrm{mol}$ trolox $\mathrm{g}^{-1}$ via the FRAP methodology (Table 4). Most likely, this can be explained by the fact that the values of total phenolic contents (TPC) and the betalains were similar in the studied samples $(\mathrm{p}>0.05)$. According to Silva et al. (2018), in red beet extracts, there is a positive correlation between TPC and antioxidant activity via the DPPH method, and between betalains content and antioxidant activity via the FRAP method.

The levels of nematode infestation studied did neither alter betalain and TPC contents nor the antioxidant potential, but there was a significant impact on the physical characteristics of the tubers, such as a reduction of mass and diameter. The extraction of betalain, for instance as a dye in the food industry, or the isolation of other antioxidant compounds, may be alternatives to minimize the losses of beets infected by M. javanica.

\section{Conclusions}

1. The population levels of Meloidogyne javanica reduce the main vegetative characteristics of beets (Beta vulgaris), namely the mass and diameter of the tuberous root.

2. The protein content decreases irrespectively of the applied inoculums levels.

3. Sugar levels, total phenolic compounds, betalains, and antioxidant activity are not reduced in the presence of M. javanica.

\section{Acknowledgments}

To Conselho Nacional de Desenvolvimento Científico e Tecnológico ( $\mathrm{CNPq})$, for the research productivity scholarship granted to the fourth author; and to the Araucária Foundation, for the Master's Degree scholarship granted to the first author.

\section{References}

ASMUS, G.L.; FERRAZ, L.C.C.B. Effect of population densities of Heterodera glycines race 3 on leaf area, photosynthesis and yield of soybean. Fitopatologia Brasileira, v.27, p.273-278, 2002. DOI: https://doi.org/10.1590/S0100-41582002000300006.

ATKINSON, N.J.; DEW, T.P.; ORFILA, C.; URWIN, P.E. Influence of combined biotic and abiotic stress on nutritional quality parameters in tomato (Solanum lycopersicum). Journal of Agricultural and Food Chemistry, v.59, p.9673-9682, 2011. DOI: https://doi.org/10.1021/jf202081t.

BAVEC, M.; TURINEK, M.; GROBELNIK-MLAKAR, S.; SLATNAR, A.; BAVEC, F. Influence of industrial and alternative farming systems on contents of sugars, organic acids, total phenolic content, and the antioxidant activity of red beet (Beta vulgaris L. ssp. vulgaris Rote Kugel). Journal of Agricultural and Food Chemistry, v.58, p.11825-11831, 2010. DOI: https://oi. org/10.1021/jf103085p.

BENKEBLIA, N.; LOPEZ, M.G. Saccharides and fructooligosaccharides composition of green and ripe Averrhoa carambola, Blighia sapida and Spondias dulcis fruits. Food Chemistry, v.176, p.314-318, 2015. DOI: https://doi.org/10.1016/j. foodchem.2014.12.080.

BOLANHO, B.C; DANESI, E.D.; BELÉIA, A.P. Carbohydrate composition of peach palm (Bactris gasipaes Kunth) by-products flours. Carbohydrate Polymers, v.124, p.196-200, 2015. DOI: https://doi.org/10.1016/j.carbpol.2015.02.021.

CARNEIRO, R.G.; MAZZAFERA, P.; FERRAZ, L.C.C.B.; MURAOKA, T.; TREVELIN, P.C.O. Uptake and translocation of nitrogen, phosphorus and calcium in soybean infected with Meloidogyne incognita and M. javanica. Fitopatologia Brasileira, v.27, p.141-150, 2002. DOI: https://doi.org/10.1590/ S0100-41582002000200004.

CARRILLO, C.; REY, R.; HENDRICKX, M.; CAVIA, M.M.; ALONSO-TORRE, S. Antioxidant capacity of beetroot: traditional vs novel approaches. Plant Foods for Human Nutrition, v.72, p.266-273, 2017. DOI: https://doi.org/10.1007/s11130-017-0617-2.

CHARCHAR, J.M.; OLIVEIRA, V.R.; ARAGÃO, F.A.S. Extração dos espécimes de Meloidogyne das raízes de tomateiros pela técnica do liquidificador. Nematologia Brasileira, v.30, p.245-250, 2006.

CHEN, M.; ZHAO, Y.; YU, S. Optimisation of ultrasonic-assisted extraction of phenolic compounds, antioxidants, and anthocyanins from sugar beet molasses. Food Chemistry, v.172, p.543-550, 2015. DOI: https://doi.org/10.1016/j.foodchem.2014.09.110. 
CLIFFORD, T.; HOWATSON, G.; WEST, D.J.; STEVENSON, E.J. The potential benefits of red beetroot supplementation in health and disease. Nutrients, v.7, p.2801-2822, 2015. DOI: https:// doi.org/10.3390/nu7042801.

DI VITO, M.; VOVLAS, N.; CASTILlO, P. Host-parasite relationships of Meloidogyne incognita on spinach. Plant Pathology, v.53, p.508-514, 2004. DOI: https://doi.org/10.1046/ j.0032-0862.2004.01053.x.

EL-SHERIF, A.G.; NOUR EL-DEEN, A.H.; IBRAHIM, D.S.S. Pathological effects of Meloidogyne incognita eggs on growth of sugarbeet and nematode reproduction under greenhouse conditions. African Journal of Agricultural Research, v.8, p.3368-3371, 2013. DOI: https://doi.org/10.5897/AJAR2013.6857.

FERREIRA, D.F. Sisvar: a computer statistical analysis system. Ciência e Agrotecnologia, v.35, p.1039-1042, 2011. DOI: https:// doi.org/10.1590/S1413-70542011000600001.

HANSE, B.; SCHNEIDER, J.H.M.; TERMORSHUIZEN, A.J.; VARRELMANN, M. Pests and diseases contribute to sugar beet yield difference between top and averagely managed farms. Crop Protection, v.30, p.671-678, 2011. DOI: https://doi.org/10.1016/j. cropro.2011.02.018.

HELD, L.J.; JENNINGS, J.W.; KOCH, D.W.; FRED, A.; GRAY, F.A. Economics of trap cropping for sugar beet nematode control. Journal of Sugar Beet Research, v.37, p.45-55, 2000. DOI: https://doi.org/10.5274/jsbr.37.1.45.

HORWITZ, W.; LATIMER JR, G.W. Official Methods of Analysis of AOAC International. $18^{\text {th }}$ ed. Gaithersburg: AOAC International, 2005. Official Methods 925.09, 923.03, and 920.87.

HOTH, S.; SCHNEIDEREIT, A.; LAUTERBACH, C.; SCHOLZSTARKE, J.; SAUER, N. Nematode infection triggers the de novo formation of unloading phloem that allows macromolecular trafficking of green fluorescent protein into syncytia. Plant Physiology, v.138, p.383-392, 2005. DOI: https://doi.org/10.1104/ pp.104.058800.

HUSSEY, R.S.; BARKER, K.R. A comparison of methods of collecting inocula of Meloidogyne spp., including a new technique. Plant Disease Reporter, v.57, p.1025-1028, 1973.

KORAYEM, A.M. Relationship between Meloidogyne incognita density and damage to sugar beet in sandy clay soil. Egypt Journal Phytopatology, v.34, p.61-68, 2006.

KORAYEM, A.M.; MOHAMED, M.M.M.; ABOU-HUSSEIN, S.D. Damage threshold of root-knot nematode Meloidogyne arenaria to potatoes grown in naturally and artificially infected fields and its effect on some tubers properties. Journal of Applied Sciences Research, v.8, p.1445-1452, 2012.

KRALL, J.M.; KOCH, D.W.; GRAY, F.A; NACHTMAN, J.J. Cultural management of trap crops for control of sugarbeet nematode. Journal of Sugar Beet Research, v.37, p.27-43, 2000. DOI: https://doi.org/10.5274/JSBR.37.1.27.

LESKOVAR, D.I. Root and shoot modification by irrigation. HortTechnology, v.8, p.510-514, 1998. DOI: https://doi. org/10.21273/HORTTECH.8.4.510.

MELAKEBERHAN, H.; MAUNG, Z.T.Z.; LEE, C.L.; POINDEXTER, S.; STEWART, J. Soil type-driven variable effects on cover- and rotation-crops, nematodes and soil food web in sugar beet fields reveal a roadmap for developing healthy soils. European Journal of Soil Biology, v.85, p.53-63, 2018. DOI: https://doi.org/10.1016/j.ejsobi.2018.01.007.

NACZK, M.; SHAHIDI, F. Extraction and analysis of phenolics in food. Journal of Chromatography A, v.1054, p.95-111, 2004. DOI: https://doi.org/10.1016/j.chroma.2004.08.059.

NAYAK, D.K.; MOHANTY, K.C. Biochemical changes in brinjal induced by root-knot nematode, Meloidogyne incognita. Indian Journal of Nematology, v.40, p.43-47, 2010.

OOSTENBRINK, M. Major characteristics of the relation between nematodes and plants. Mededelingen van de Landbouwhogeschool, v.66, p.1-46, 1966.

PETEK, M.; ĆUSTIĆ, M.H.; TOTH, N.; SLUNJSKI, S.; ČOGA, L.; PAVLOC, I.; KARAZIJA, T.; LAZAREVIČ, B.; CVETKOVIČ, S. Nitrogen and crude proteins in beetroot (Beta vulgaris var. conditiva) under different fertilization treatments. Notulae Botanicae Horti Agrobotanici Cluj-Napoca, v.40, p.215219, 2012. DOI: https://doi.org/10.15835/nbha402745.

PREMACHANDRA, W.T.S.D.; GOWEN, S.R. Influence of preplant densities of Meloidogyne incognita on growth and root infestation of spinach (Spinacia oleracea L.) (Amaranthaceae) - an important dimension towards enhancing crop production. Future of Food: Journal on Food, Agriculture and Society, v.3, p.18-26, 2015.

RAVICHANDRAN, K.; AHMED, A.R.; KNORR, D.; SMETANSKA, I. The effect of different processing methods on phenolic acid content and antioxidant activity of red beet. Food Research International, v.48, p.16-20, 2012. DOI: https://doi. org/10.1016/j.foodres.2012.01.011.

RAVICHANDRAN, K.; SAW, N.M.M.T.; MOHDALY, A.A.A.; GABR, A.M.M.; KASTELL, A.; RIEDEL, H.; CAI, Z.; KNORR, D.; SMETANSKA, I. Impact of processing of red beet on betalain content and antioxidant activity. Food Research International, v.50, p.670-675, 2013. DOI: https://doi.org/10.1016/j. foodres.2011.07.002.

ROSA, J.M.O.; WESTERICH, J.N.; WILCKEN, S.R.S. Reprodução de Meloidogyne enterolobii em olerícolas e plantas utilizadas na adubação verde. Revista Ciência Agronômica, v.46, p.826-835, 2015. DOI: https://doi.org/10.5935/18066690.20150071.

SAWICKI, T.; BĄCZEK, N.; WICZKOWSKI, W. Betalain profile, content and antioxidant capacity of red beetroot dependent on the genotype and root part. Journal of Functional Foods, v.27, p.249-261, 2016. DOI: https://doi.org/10.1016/j.jff.2016.09.004.

SILVA, H.R.P. da; SILVA, C. da; BOLANHO, B.C. Ultrasonicassisted extraction of betalains from red beet (Beta vulgaris L.). Journal Food Process Engineering, v.41, e12833, 2018. DOI: https://doi.org/10.1111/jfpe.12833.

STAGNARI, F.; GALIENI, A.; SPECA, S.; PISANTE, M. Water stress effects on growth, yield and quality traits of red beet. Scientia Horticulturae, v.165, p.13-22, 2014. DOI: https://doi. org/10.1016/j.scienta.2013.10.026. 
TAIZ, L.; ZEIGER, E.; MØLLER, I.M.; MURPHY, A. Fisiologia e desenvolvimento vegetal. 6.ed. Porto Alegre: Artmed, 2017. 858p.

TIVELLI, S.B.; FACTOR, T.L.; TERAMOTO, J.R.S.; FABRI, E.G.; MORAES, A.R.A. de; TRANI, P.E.; MAY, A. Beterraba: do plantio à comercialização. Campinas: Instituto Agronômico, 2011. 45p. (Série Tecnologia APTA. Boletim Técnico IAC, 210).

USDA. United States Department of Agriculture. Agricultural Research Service. Available at: <http://www.ars.usda.gov>. Accessed on: Mar. 202019.

VOVLAS, N.; MIFSUD, D.; LANDA, B.B.; CASTILLO, P. Pathogenicity of the root-knot nematode Meloidogyne javanica on potato. Plant Pathology, v.54, p.657-664, 2005. DOI: https:// doi.org/10.1111/j.1365-3059.2005.01244.x.
WOOTTON-BEARD, P.C.; MORAN, A.; RYAN, L. Stability of the total antioxidant capacity and total polyphenol content of 23 commercially available vegetable juices before and after in vitro digestion measured by FRAP, DPPH, ABTS and Folin-Ciocalteu methods. Food Research International, v.44, p.217-224, 2011. DOI: https://doi.org/10.1016/j.foodres.2010.10.033.

WRUSS, J.; WALDENBERG, G.; HUEMER, S.; UYGUN, P.; LANZERSTORFER, P.; MÜLLER, U.; HÖGLINGER, O.; WEGHUBER, J. Compositional characteristics of commercial beetroot products and beetroot juice prepared from seven beetroot varieties grown in Upper Austria. Journal of Food Composition and Analysis, v.42, p.46-55, 2015. DOI: https://doi.org/10.1016/j. jfca.2015.03.005. 